\title{
Macroscopic description of teeth of Azara's agouti (Dasyprocta azarae) ${ }^{1}$
}

\author{
Fabrício S. Oliveira ${ }^{2 *}$, Leandro L. Martins ${ }^{3}$, Júlio C. Canola ${ }^{3}$, Paulo T. Oliveira ${ }^{4}$, Jesus D. Pécora ${ }^{4}$ \\ and Ana P. Pauloni ${ }^{5}$
}

\begin{abstract}
Oliveira F.S., Martins L.L., Canola J.C., Oliveira P.T., Pécora J.D. \& Pauloni A.P. 2012. Macroscopic description of teeth of Azara's agouti (Dasyprocta azarae). Pesquisa Veterinária Brasileira 32(1):93-95. Departamento de Medicina Veterinária, Universidade Estadual de Maringá, Campus Umuarama, Cx. Postal 65, Umuarama, PR 87501-970, Brazil. E-mail: singaretti@ig.com.br

The teeth of Azara's agouti (Dasyprocta azarae) were described macroscopically in order to provide biological data on one of the largest wild rodents of the Americas. Radiography was taken on six heads and the teeth were described. Enamel surrounds the coronal dentin, projects to the roots and is present as parallel inner laminae in buccolingual direction. The dentin is located among the enamel laminae and surrounds the pulp horns. The cementum is located internally to the enamel laminae. On the lingual surface, the cementum and dentin are the outer elements.
\end{abstract}

INDEX TERMS: Anatomy, teeth, macroscopy, Dasyprocta azarae, agouti.

RESUMO.- [Caracterização macroscópica dos dentes de cutias (Dasyprocta azarae).] Os dentes de cutias (Dasyprocta azarae) foram descritos macroscopicamente para fornecer informações sobre um dos maiores roedores das Américas. Radiografias foram realizadas em seis cabeças, e os dentes foram descritos. 0 esmalte envolve a dentina coronal e se projeta até a raiz e é presente como lâminas dispostas paralelamente em direção vestíbulolingual. A dentina é localizada entre as lâminas do esmalte e envolve os cornos pulpares. 0 cemento é localizado internamente às lâminas de esmalte. Na superfície lingual, o cemento e a dentina são os elementos mais externos.

TERMOS DE INDEXAÇÃO: Anatomia, dentes, macroscopia, Dasyprocta azarae, cutia.

\section{INTRODUCTION}

The Azara's agouti (Dasyprocta azarae) is the third largest Brazilian wild rodent, found throughout the forest, where

\footnotetext{
${ }^{1}$ Received on July 16, 2011.

Accepted for publication on October 20, 2011.

2 Departamento de Veterinária, Universidade Estadual de Maringá (UEM), Campus Umuarama, Cx. Postal 65, Umuarama, PR 87501-970, Brazil. Autor para correspondência: singaretti@ig.com.br

${ }^{3}$ Departamento de Clínica e Cirurgia, Via de Acesso Paulo Donato Castelane $s / n$, Universidade Estadual de São Paulo (Unesp), Jaboticabal, SP 14884-900, Brazil.

${ }^{4}$ Departamento de Morfologia, Fisiologia e Estomatologia, Universidade de São Paulo (USP), Ribeirão Preto, SP 14040-904, Brazil.

${ }^{5}$ Departamento de Odontologia Restauradora, USP, Ribeirão Preto, SP 14040-904.
}

it lives mainly on fallen fruits and nuts (Lange \& Schimidt 2007).

Rodents have only one set of teeth rather than a primary and permanent set (Crossley 1995) and two pairs of chiseled incisors (Villee et al. 1985). The agouti's upper and lower incisors are long, curved, brown and chiseled. The lower are thinner and longer than the upper incisors. There are four posterior teeth in each hemiarch (Leão 2002), which are not classified as premolars or molars.

The aim of the present study was to macroscopically describe the teeth of Azara's agouti, an animal of increasing scientific interest, as shown in recent papers about the axial (Oliveira et al. 2009a) and apendicular (Oliveira et al. 2009b) skeletons, besides anesthesia (Oliveira et al. 2006), surgery (Martins et al. 2009) and determination of the basal metabolic rate (Brito et al. 2010).

\section{MATERIALS AND METHODS}

Following the natural death of three adult agouti (Dasyprocta azarae Lichtenstein, 1823) males and three adult females belonging to the Catanduva City Zoo, SP, Brazil, animals were radiographed for dental analysis. Incisors, premolars and molars were extracted, described, identified and kept in individual dark plastic containers with $0.1 \%$ thymol solution for conservation at $4^{\circ} \mathrm{C}$ until use. The teeth were then washed in running water for one day, dried with jets of air, embedded in acrylic resin with fast polymerization (Resina Acrílica Jet ${ }^{\mathrm{TM}}$, São Paulo, Brazil) and cut on a microtome with a diamond disc. Sections of approximately 700 $\mu \mathrm{m}$ were obtained and filed under running water until reaching 


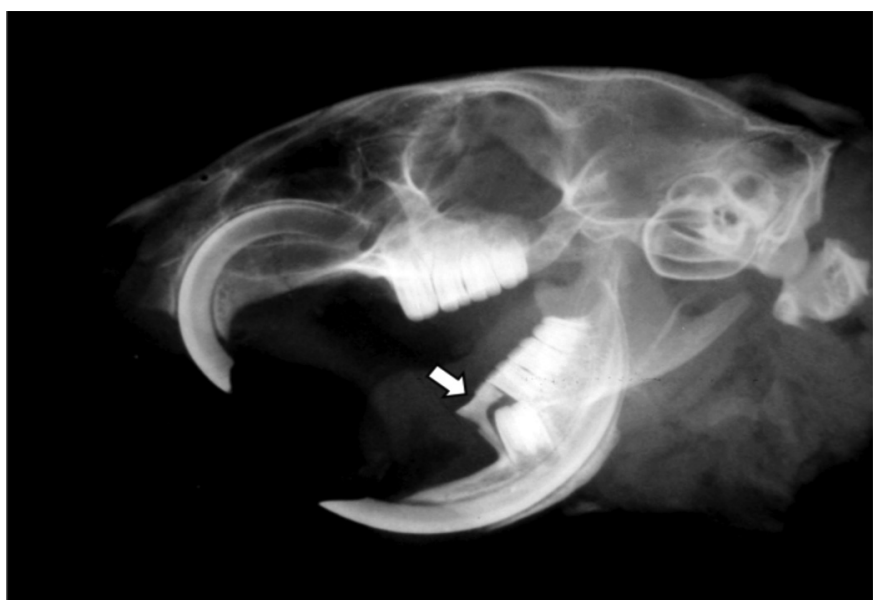

Fig.1. Lateral radiograph of the head of an agouti presenting a lower deciduous premolar (arrow) in eruption.

$100 \mu \mathrm{m}$. Sections were dehydrated in alcohol, clarified in xylol and photographed under a magnifying glass (Pécora 1992).

\section{RESULTS AND DISCUSSION}

There were no differences in tooth structure between males and females. One radiograph revealed a deciduous tooth and its permanent successor, which was classified as lower premolar, because molars do not have a deciduous form.
The other three teeth in each hemiarch presented no deciduous form in any radiograph and were classified as molars (Fig.1), similar to that found in the paca (Oliveira \& Canola 2007), in the rock cavy (Kerodon rupestris) (Thomaz et al. 2006) and in the chinchilla (Chinchilla laniger) (Crossley 2001). However, a complete radiographic study during the entire tooth eruption process is needed to precisely determine premolars and molars.

The teeth of Azara's agouti do not exhibit a distinguished crown and root because the enamel is present throughout virtually the entire length of the tooth, together with the cementum. This differs from teeth of domestic mammals (Dyce et al. 2010) and humans (Ten Cate 2001), in which there is evident separation of these regions.

The Azara's agouti presents a pair of upper and lower rootless scalpriform incisors, due to the enamel on the labial surface and little cementum or dentin on the lingual surface. In those teeth, the enamel is the element situated more externally in the buccal surface and is in contact with the dentin. In the lingual surface, the cementum and dentin are the most external elements, similar to the paca. Also like the paca (Oliveira et al. 2006), the lower incisors presented greater length in relation to the other ones and sinuous shape; the upper incisors are relatively smaller.

Like the paca (Oliveira et al. 2006) and equines, there are infundibular recesses or depressions on the occlusal
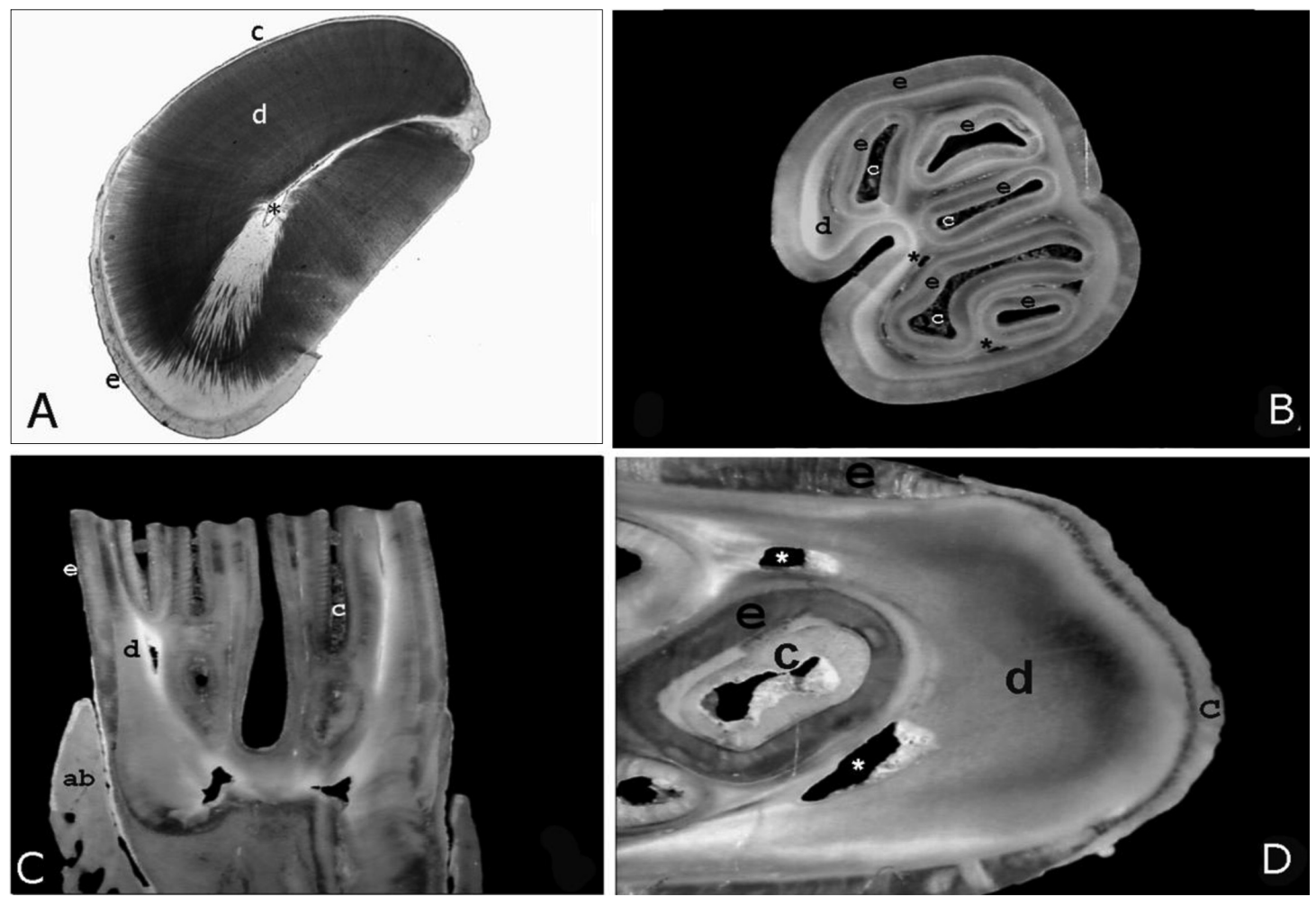

Fig.2. (A) Cross section of the lower incisor of an adult agouti; enamel (e) in the buccal region; cementum (c) and dentin (d) in the lingual surface and the pulp horn in the tooth central area $\left.{ }^{*}\right)$. (B) Cross section of the first right upper molar of an adult agouti near the occlusal surface; enamel (e) surrounds the tooth and is present as internal laminae; dentin (d) is located among those laminae, in which pulpar horns (*) are situated; cementum (c) locates internally to some laminae of enamel. (C) Mesiodistal section of an adult agouti molar; the enamel (e), the dentin (d), the cementum (c) and the alveolar bone (ab) are evident. (D) Apical area of C; the enamel laminae (e), besides the cementum (c), dentin (d) and pulp horns $\left(^{*}\right)$, are remarkeable in dental root. 
surface of premolars and molars of agoutis, which are surrounded by enamel containing cementum internally. This constitutes an uneven file-like masticatory surface similar to that found in equines (Dyce et al. 2010, König et al. 2004). Like the premolars and molars of the paca (Oliveira et al. 2006), the agouti have laminae or sheets of enamel surrounded by cementum, like several teeth joined together (Fig.2).

The dentin constitutes most of the tooth in the agouti and contains the central cavity that lodges the pulp of the connective tissue, as in domestic mammals (Dyce et al. 2010).

\section{REFERENCES}

Brito H.F.V., Lange R.R., Pachaly J.R. Deconto I. 2010. Determinação da taxa metabólica basal em cutias, Dasyprocta azarae, por calorimetria indireta. Pesq. Vet. Bras. 30(6):471-478.

Crossley D.A. 1995. Clinical aspects of rodent dental anatomy. J. Vet. Dent. 12:131-135.

Crossley D.A. 2001. Dental disease in chinchillas in the UK. J. Small Anim. Pract. 42:12-19.

Dyce K.M., Sack W.O. \& Wensing C.J.G. 2010. Tratado de Anatomia Veterinária. Elsevier, Rio de Janeiro. 834p.

König H.E. \& Liebich H.-G. 2004. Anatomia dos Animais Domésticos. Artmed, Porto Alegre. 400p.

Leão P.M.M., Moura W.L. \& Carvalho P.V. 2001. Descrição anatômica dos elementos dentários de Dasyprocta aguti. Anais 1o Congresso Internacional de Odontologia do Piauí, Teresina, p.16.
Martins L.L., Oliveira F.S., Rodrigues V., Toniollo G.H. \& Machado M.R.F. 2010. Ovariossalpingohisterectomia em cutias (Dasyprocta azarae Lichtenstein, 1823): uso de técnica convencional. Pubvet 4:779.

Oliveira F.S. \& Canola J.C. 2007. Erupção dental em pacas (Agouti paca) criadas em cativeiro. Arq. Bras. Med. Vet. Zoo 59:390-394. (Online)

Oliveira F.S., Canola J.C., Oliveira P.T., Pécora J.D. \& Capelli A. 2006. Anatomoradiographic description of the teeth of pacas bred in captivity. Anat. Histol. Embryol. 35:316-318.

Oliveira F.S., Canola J.C., Oliveira P.T., Pécora J.D. \& Capelli A. 2007. Microscopic characterization of teeth of pacas bred in captivity (Agouti paca Linnaeus, 1766). Anat. Histol. Embryol. 2:2-4.

Oliveira F.S., Martins L.L., Pauloni A.P., Machado M.R.F., Toniollo G.H. \& Canola J.C. 2009a. Descrição anátomo-radiográfica do esqueleto axial da cutia (Dasyprocta azarae Lichtenstein, 1823). Ars Vet. 25:20-23.

Oliveira F.S., Martins L.L., Pauloni A.P., Toniollo G.H., Canola J.C. \& Machado M.R.F. 2009b. Descrição anátomo-radiográfica do esqueleto apendicular da cutia (Dasyprocta azarae Lichtenstein, 1823). Ars Vet. 25:24-27.

Pécora J.D. 1992. Efeitos das soluçoes de Dakin e de EDTA, isoladas, alternadas e misturadas, sobre a permeabilidade da dentina radicular. Tese de Livre-Docência, Universidade de São Paulo, Ribeirão Preto, SP.

Ten Cate A.R. 2001. Histologia Bucal: desenvolvimento, estrutura e função. Guanabara Koogan, Rio de Janeiro. 439p.

Villee C.A, Walker J.R. \& Barnes R.D. 1985. Zoologia Geral. Interamericana, Rio de Janeiro. 548p.

Thomaz J.M., Carvalho A.F., Miglino M.A., Maçanares C.A.F., Ambrósio C.E. \& Oliveira M.F. 2006. Caracterização morfológica dos dentes de mocó Kerodon rupestris (Mammalia: Rodentia). Braz. J. Vet. Res. Anim. Sci. 43:702-707. 